Preprint of: Garner, June, Davidson, Karen, and Williams, Virginia Kay. (June 2008). Identifying Serials Trends through Twenty Years of NASIG Conference Proceedings: A Content Analysis.

Serials Review 34(2): 88-103.

Note that all tables and figures appear after text.

Identifying Serials Trends through Twenty Years of NASIG Conference Proceedings: A

\title{
Content Analysis
}

Abstract: The North American Serials Interest Group (NASIG), founded in 1985, holds annual conferences to promote communication among librarians, publishers, subscription agents, and others in the serials information chain. The authors used qualitative and quantitative content analysis to identify the major topics discussed at the first twenty NASIG conferences, analyze how the popularity of topics has changed over time, and compare NASIG topics to issues being discussed in the serials literature.

\section{Introduction}

The North American Serials Interest Group (NASIG) was established in 1985 to fulfill a need for communication, sharing of ideas, and continuing education among members of the serials information chain. NASIG is an independent organization consisting of librarians, publishers, vendors, educators, database producers, library system representatives and many others involved in serials information creation, production, delivery, management, and access. NASIG conferences offer insight into innovations, issues, and emerging technologies in the serials world. ${ }^{1}$ Today NASIG is known as the premier North American organization for serials professionals. To identify trends in serials from 1986 to 2005 , the authors conducted a content analysis of presentations given at the first twenty NASIG conferences based on the conference proceedings published in Serials Librarian. 
The authors studied the NASIG conference proceedings because they provide a rich data source for identifying trends in the serials profession. Not only are the conference proceedings readily available, but they are also detailed and comprehensive. Studies of library conference proceedings are rare and tend to focus on presenters instead of analyzing topics; this paper examines topics and compares them with trends discussed in the literature. This analysis will also help fill a gap in the literature on serials trends; while serials literature reviews exist for 1986-1992 and 2000-2003, none cover the period from 1993 through 2000.

The authors analyzed the first twenty years of NASIG proceedings in order to answer the following questions:

- Which topics have been discussed most frequently?

- Has the popularity of topics changed over time? If so, how?

- Has the emphasis on a particular topic changed over time? If so, how?

- Are some topics, such as collection development and resource sharing, frequently discussed together?

- Have the topics discussed at NASIG reflected the trends identified in reviews of the serials literature?

\section{Literature Review}

Content analysis is "a research technique for making replicable and valid inferences from texts (or other meaningful matter) to the contexts of their use."2 As White and Marsh note in their examination of content analysis use in library and information science, content analysis is a

flexible method that can use quantitative, qualitative, or mixed techniques to analyze messages. ${ }^{3}$ Several articles discuss the value of content analysis and how it can be used in library and information science. Blessinger and Frasier observed that analyzing a field of literature using 
content analysis can bring an understanding of a profession and its development as well as determine subject trends and major issues surrounding the profession. By examining a decade of library literature, they determined that content analysis has been used for a variety of purposes within the library profession, including assisting librarians in making decisions about collection development, as a tool to identify bibliometric trends, as a way for publishers to make constructive decisions and track the competition, and as a way for researchers to track characteristics of top-cited authors and their publication record through time. Blessinger and Frasier also noted that the library literature of 1994-2004 reflected the profound impact new technologies had in almost every aspect of librarianship and on librarianship as a profession. ${ }^{4}$ Allen examined the literature to determine if and how content analysis was being used in library and information science research. He examined 36 articles from 1984-1989 to determine the types of input documents used (books, periodicals, or other document formats) and the method of content analysis used (classification or elemental analysis). His study concluded that content analysis was being used to explore a variety of library and information science questions and that the techniques of content analysis had potential for library and information science research. ${ }^{5}$ Buttlar concluded that content analysis can document the historical development of librarianship and reflect trends in the concerns and issues that are important to library and information science educators and practitioners. ${ }^{6}$ Rowley stated that analyzing conference proceedings can be a valuable tool for examining the literature of a profession, and identified a number of ways conference literature can be used, such as: learning new areas of research and development, gaining knowledge of past achievements, activities, and contributions of leaders in the profession, achieving insight into current problems and issues, and to discover solutions through experiences of others. ${ }^{7}$ In his 1988 analysis of subject trends in library and information science 
research, Atkins analyzed distribution patterns of 32 subjects over a ten-year period, classifying the subjects into five categories: boom topics, declining topics, roller coaster issues, stable subjects, and bell-shaped curve issues. ${ }^{8}$ Buttlar's analysis of sixteen library periodicals found that library automation, management, library information science education, and cataloging were the top subjects discussed from 1987 to $1989 .{ }^{9}$ In their content analyses of North American and Danish journal literature, Jarvelin and Vakkari and Kajberg found that LIS research is centered around traditional professional topics, with the theoretical aspects of librarianship and information science receiving little attention. ${ }^{10,11}$

In addition to doing a content analysis of NASIG proceedings, the authors wanted to compare their findings to serials trends noted in reviews of the library literature. Annual literature reviews examined serial trends throughout the years 1986 to 1993. Stankus reviewed the serials literature in 1986 and 1987, and identified the dominant theme of the 1986 serials literature as the automation of serials control, with a major cataloging issue of handling title changes and significant descriptive changes. The 1986 literature also included a number of articles about the necessity of cancellations in light of budget cuts and raising journal prices. ${ }^{12}$ Stankus reported that serials publications and serials management tools available through online services or on CD-ROM was the dominant theme of 1987, but print and images stored on optical devices, equipment obsolescence through incompatibility, cooperative inventories and union lists, rising journal costs, and binding issues were also discussed in the literature. ${ }^{13}$ Davis reviewed the serials literature of 1988 and 1989, and identified the serials pricing dilemma as a major theme in the 1988 literature, with other major topics including development of union lists, serials catalog conversion projects, and the anticipated demise of successive entry cataloging. Serials automation, electronic technology, serials publishing, evaluation of serials' vendors and 
vendor automation were also discussed in the 1988 literature. ${ }^{14}$ Davis reported that the dominant themes of the 1989 serials literature were serials pricing, scholarly communication, journal publishing, and access versus ownership, while serials cataloging articles focused on loose leafs and title changes. The 1989 serials literature also discussed price studies and CD-ROM technology searching techniques for full-text databases. ${ }^{15}$ According to Lonberger, the 1990 serials literature focused on the serials pricing crisis, the publishing industry, the scholarly communication process, and cancellation projects, with fewer articles about automated serials systems and their implementation than in previous years. Lonberger also noted that format integration, form of entry, and information-seeking behavior of academic library users were recurrent themes in the 1990 serials literature. ${ }^{16}$ Reimer commented that the 1991 literature showed a continuing search for affordable access to serials literature, with numerous reports of use studies to evaluate the journal collection and inform cancellation projects. The 1991 literature also discussed how libraries were adding electronic serials to collections, consistent and appropriate cataloging rules of entry, collaboration in technical services work, and skills needed to accomplish the new tasks of serials librarianship. ${ }^{17}$ Riddick found that while cataloging and the development of electronic journals dominated the 1992 literature, discussions of CD-ROM serials and pricing studies were also common. ${ }^{18}$

In addition to the literature review on serials trends, three literature reviews on closely related topics provided points of comparison for the NASIG conferences from 1989 to 2000. In a review of 1989 technical services automation literature, Kaplan found that the literature addressed how new technologies were changing the way libraries operate and how technical services librarians were change agents analyzing, learning, teaching, and managing these new systems. ${ }^{19}$ Williams examined serials cataloging literature from 1991-1996, noting the 
emergence of e-journal cataloging as a topic in the literature, finding that much of the literature focused on cataloging electronic resources, and observing that preservation and archiving of electronic resources was also discussed. ${ }^{20}$ Copeland reviewed the literature specific to electronic serials cataloging in the 1990s, finding that by the late 1990s, numerous articles were written not only on how to catalog e-serials, but also on other related issues including inadequacy of AACR2 for electronic resources, metadata as an alternative to full MARC cataloging for e-resources, and cataloging tools. ${ }^{21}$

When Silva examined the serials literature of 2002, she noted that in the decade since the last annual serials review article, CD-ROM serials had almost disappeared from the literature. The 2002 serials literature focused on managing and adapting to an increasing electronic environment across topics such as cataloging, collection management, and serials management. Pricing remained an issue not only for the present, but for the future of scholarly publishing. ${ }^{22}$ Corbett limited her review of the 2000-2003 serials literature to the broad topics of cost, management, and archiving. She noted that the literature was dominated by the topic of electronic journals, with concern expressed about access vs. ownership as libraries increased expenditures for e-journal subscriptions while continuing to subscribe to the print. Sustainability of pricing with consortial purchasing and subscriptions to large collections of e-journals, skills that librarians and staff need in order to work with electronic resources, and preservation and the various obstacles associated with archiving electronic information were also discussed in the 2000-2003 literature. ${ }^{23}$

\section{NASIG Methodology}

To identify trends in serials, the authors conducted a content analysis of presentations at NASIG conferences. The reports of the first twenty conferences published in Serials Librarian 
were used as a surrogate for the live presentations. The published reports are not perfect surrogates; while a few were papers written by the presenters or were transcripts, most reports were written by a volunteer who attended the presentations. NASIG does encourage presenters to review reports drafted by volunteers, but no data is available on how many presenters do review and edit reports of their presentations before publication. Since this research focused on identifying major ideas, the authors considered published reports an acceptable surrogate.

The authors created a relational database to record information about each presentation. The title, presenter name(s), and conference number were transcribed into the database. Session type was also coded for each presentation, based on the type indicated in the proceedings. The session type names have varied over two decades, so each time a new session type appeared, the authors examined the proceedings introductions to determine if the new session type was equivalent to one previously used. When it was, the authors combined the session type names so all session types with the same purpose were coded alike. The session types were coded as paper/panel, preconference, strategy/concurrent/issue/project, tactics/workshop, or vision/plenary/keynote. This identifying data was initially transcribed from the table of contents of each proceeding. Several presentations were later deleted from the database when the authors discovered that only an abstract had been published or that the presentation was actually a brief closing session that summarized all presentations at that conference. In addition, the authors decided to omit poster sessions because only abstracts were published.

The authors considered using the controlled vocabulary subject descriptors assigned in Library Literature for subject coding. However, after searching each presentation in Library Literature and recording the subject descriptors, the authors decided that the descriptors lacked the desired specificity for this content analysis. The authors also considered using the indexing 
terms from the conference monographs published by Haworth, but decided that the proceeding indexes were too detailed for analysis of major topics.

The authors developed a thematic coding scheme. They read all published conference reports to develop an understanding of the range of topics discussed at NASIG. As they read, the authors noted keywords and phrases describing the presentations. After extensive discussions, the authors categorized the keywords and phrases to identify and define the following sixteen major topics or categories:

- Access vs. ownership: Discussions of philosophical, financial, legal, and other issues of deciding whether to purchase materials or provide access to materials through licensing agreements and resource sharing arrangements.

- Acquisitions: Activities related to acquiring materials after a selection decision has been made, including ordering, invoicing, and negotiating licenses.

- Bibliographic control: Providing access to information through activities such as cataloging, A-Z list creation, metadata creation.

- Collection development: Selecting, evaluating, and deselecting information resources.

- Economics of information: Discussions of economic trends, costs, prices, budgets, and financial issues.

- Future of serials: Predictions about serials and their role in scholarly communication process.

- Preservation and perpetual access: Ensuring that information remains available for many decades and centuries through activities such as archiving, disaster preparedness, binding, and planning for perpetual access. 
- Professional issues and skills: Career development topics such as education for librarianship, alternative careers, time management, presentation skills, and web page creation skills.

- Resource sharing: Sharing resources through activities such as interlibrary loan, document delivery, cooperative collection development, and consortia activities.

- Scholarly information issues: Discusses issues such as peer review, copyright, intellectual property rights, open access, tenure requirements, and the scholarly communication process.

- Serials industry: Activities of publishers, vendors, and subscription agents, including their relationships with libraries.

- Serials management: Managing serials in libraries through activities such as check-in, processing, serials control, authentication, and license management. (Note: Ordering and invoicing are acquisitions.)

- Standards development: Developing and revising standards, including standards for cataloging.

- Technology impact: Discussions of activities made possible by or required to adapt to changing technologies. Examples include automating library operations, cataloging or managing new formats such as CD-ROMs, learning new methods of communication such as email.

- Users and public services: Discussions of end users and public service activities. Includes generational issues and changing expectations.

- Workflow and staffing: Designing workflows and managing staff, including training staff as workflows change. 
The authors agreed to code based on the extent to which each topic was present: a topic would be coded as predominant if at least $60 \%$ of the report concerned that subject, major if at least $20 \%$ but less than $60 \%$, and insignificant if less than $20 \%$ of the report concerned that subject. The authors also agreed that a presentation could have two predominant categories; for example, a discussion of implementing an automated serials control system could be coded predominant for both technology impact and serials management.

The authors selected a random 5\% sample of the presentations to test the preliminary coding plan. Each author coded the presentations. The authors calculated Cohen's Kappa using PRAM: a Program for Reliability Assessment with Multiple Coders to test intercoder reliability. ${ }^{24}$ The overall Cohen's Kappa was 0.944 , with no category achieving a Cohen's Kappa lower than 0.91 . Reliability coefficients of 0.9 or higher are generally considered to indicate excellent intercoder reliability. ${ }^{25}$ The authors discussed each instance where they differed on coding, negotiated until they agreed, and finalized the definitions in the coding scheme.

After finalizing the coding scheme, the authors coded the remaining presentations. Where all three authors did not agree, they negotiated the appropriate coding. In every case, the disagreement was about the extent to which a topic was discussed during a presentation; they agreed on the topics that were discussed, but differed on which were major and which were predominant. To negotiate these differences, the authors reviewed the conference report, identifying which sections discussed each topic. In most cases, the authors decided that no topic was predominant and coded several categories as major.

After all presentations were coded, a correlation matrix was constructed to determine whether some topics were frequently discussed together. A Pearson correlation coefficient was calculated for each pair of subject topics with significance tested at the 0.01 and 0.05 levels. 
The authors graphed the number of presentations for each topic by year to determine whether distribution patterns like the ones Atkins described could be identified. To determine whether the emphasis on a particular topic had changed over time, the authors examined each topic's presentations in chronological order and noted changing trends and the issues discussed. Next, they reviewed the individual presentations coded to the same topic by year in order to identify trends. Finally, the authors compared the trends identified from the NASIG conferences with trends noted in published reviews of the serials literature.

\section{Findings}

Out of all of the presentations given during the first twenty conferences, a total of 738 presentations met the authors' criteria for this research project. The number of presentations per conference ranged from a low of eighteen at the second conference in 1987 to a high of 54 at the conference in 1998. As can be seen in Figure 1, the conferences with the lowest number of presentations were early in NASIG's history. The number of presentations per conference rose steadily until 1987, then declined slightly to offer attendees 35-40 sessions per conference.

\section{[Insert Figure 1]}

Conferences were organized around different types of sessions: paper/panel, preconference, concurrent/strategy, tactics/workshop, or vision/plenary/keynote. Table 1 shows the number of each type of session offered each year. Session type names changed over the years; the authors examined the goals of each session type and grouped those with the same goals together. At each conference, a few presenters were asked to share their thoughts and interpretations on broad issues and concepts that could influence the serials world $;{ }^{26}$ these sessions were called keynotes from 1986-1990, plenaries from 1991-2003, and visions beginning 
in 2004. During the first five conferences, paper and panel sessions were offered. Some addressed universal issues and concepts, while others focused on more pragmatic issues.

\section{[Insert Table 1]}

Workshops, renamed tactics in 2004, were offered at every conference.

Tactics/workshops focused on one or two practical aspects of the serials world, giving attendees the opportunity to learn about specific day-to-day issues. The featured topics were often focused to address the interests of specific audiences.

Concurrent sessions were first offered at the $7^{\text {th }}$ annual conference in 1992. As the name implies, these sessions were scheduled simultaneously, requiring attendees to select between one or more offerings in a given conference time slot. Sessions may or may not have been repeated at other times during the conference. Concurrent sessions were intended to attract a mixed audience of publishers, vendors, and librarians by approaching topics from a broader focus than workshops. ${ }^{27}$ At times, concurrent sessions were known as projects or issues sessions. Beginning in 2004, the name was changed to strategy session.

Preconferences were introduced at NASIG in 1992 and have been held every year since except for 1995. They provided attendees opportunities to learn and practice skills in a hands-on setting.

As can be seen in Figure 1, the conference with the most sessions also had the most topics assigned. The sixteen categories defined for this study were assigned 1,437 times across the 738 sessions. Two-thirds were coded to multiple topics, with the average number of categories coded major or predominant for a session being 1.95. The number of categories coded major or predominant ranged from zero to five per presentation. The only presentation that did not fit any of the sixteen categories was a plenary presentation, "Painting America Purple: Media 
Democracy and the Red/Blue Divide," from the $20^{\text {th }}$ conference. The only session coded to five categories was a 1998 strategy session, "Coping with the Digital Shift: Four of the Thorniest Issues," which was coded to preservation, resource sharing, serials management, technology impact, and economics of information. More than half the presentations were coded with predominant topics but with no major topics, but only 21 presentations were coded with major topics but with no predominant topic. Major-only coding could indicate that several of the defined categories were discussed, but none was discussed in at least $60 \%$ of the presentation; it could also mean that topics which did not fit the defined categories were discussed extensively in that presentation. Table 2 shows the extents to which presentations were coded to multiple topics.

\section{[Insert Table 2]}

The sixteen topics defined for this study range from the most frequently assigned, technology impact, which was assigned to 353 (47.9\%) different presentations, to the least discussed topic, access vs. ownership, assigned to only 25 (3.4\%) presentations. Table 3 shows the categories ranked by the number of presentations to which they were assigned, while Table 4 summarizes coding by category and year.

[Insert Table 3]

[Insert Table 4]

The authors suspected that some topics might tend to be discussed in the same presentations frequently. For example, it seemed likely that economics of information would frequently be discussed with collection development since limited budgets require libraries to select titles instead of subscribing to every title available. However, the authors found that only five of the 136 pairs were positively correlated at the 0.05 (two-tailed) significance level. For 
example, as shown in Table 5, a significant but weak positive correlation between access vs. ownership and resource sharing was found; however, given the implicit relationship between access and resource sharing, the authors were surprised the correlation was not stronger. The authors decided not to further investigate whether topics were frequently discussed together since only a few weak correlations were found.

\section{[Insert Table 5]}

\section{Technology Impact}

Technology's impact on library services was a prominent topic discussed at the first twenty NASIG conferences. As technologies changed and developed, libraries adapted by automating library operations, cataloging and managing new formats such as CD-ROMs and ejournals, and adopting new methods of communication such as email. Almost half of the presentations, 353 out of 738, discussed the impact of technology. Slightly more than one-third of the presentations were coded predominant for technology impact. In addition to being the most frequently assigned subject code overall, technology impact was the most frequently assigned subject code in 1986 and 1988-2002. Table 4 shows the number of times each topic was assigned by year

In his study of library literature from 1975 to 1984, Atkins noted a bell-shaped curve for some subjects as showing a "slow start and finish but with a number of boom years in between." 28 The authors noted that during the first twenty NASIG conferences, graphing technology impact presentations produced a bell-shaped curve like the one Atkins described. Technology impact had a slow start at NASIG with 5-10 presentations per year from 1986 to 1990, rose to a peak of 40 out of 54 presentations in 1998, and then steadily declined to only 6 presentations per year in 2004 and in 2005. The authors also noted that during the early 
conferences, the impact of technology was frequently the focus of presentations, with a large proportion of the presentations coded as predominant in that subject category. But in more recent years, technology impact has more often been discussed as one aspect of another topic, so technology impact was coded major. Figure 2 illustrates the bell-shaped curve of technology impact and shows the shift from technology impact as the focus of presentations to it being discussed as one aspect of some other topic.

\section{[Insert Figure 2]}

Stankus noted that the automation of serials processing was a dominant theme of the serials literature in $1986,{ }^{29}$ so it is not surprising that the major technology topic discussed during the first NASIG conference was automation of serials control systems. In 1986, forty percent of NASIG presentations focused on developing serials control systems. Serials automation was discussed at all but three NASIG conferences (1994, 2004, and 2005), but other technology topics dominated after the first two conferences.

From 1988 to 2000, new information formats were the major technology topics at NASIG. New formats were also a hot topic in the serials literature, with many articles about search capabilities of new electronic products in $1988,{ }^{30}$ extensive discussion of CD-ROMs in $1989,{ }^{31}$ and the emergence of cataloging e-serials as a new topic in the early $1990 \mathrm{~s}^{32}$ At the 1989 conference, five presentations discussed dealing with CD-ROMs, ranging from considerations in selecting CD-ROMs to cataloging and processing them. The CD-ROM format was still being discussed at NASIG in 1993, but multimedia was taking the lead as an important topic with four presentations discussing its usefulness for conveying information and problems in managing multimedia files. A new tool for serialists, NASIGnet, was also introduced at the 1993 conference. Blessinger and Frasier noted that "[t]he Internet, as we all know, has changed most 
aspects of our profession...," ${ }^{, 33}$ so it is unsurprising that new information formats and tools made possible by the Internet were frequently discussed at NASIG during the 1990s. In 1994, new online tools for serials professionals were a hot topic, with presentations on using electronic mailing lists, gophers, and even one on the Mosaic web browser. While online indexing and abstracting services had been discussed at NASIG previously, the years 1995 to 1997 were replete with discussions of full-text electronic journal projects. Libraries, learned societies, and commercial publishers reported on projects to create core collections of full-text journals, digitize selected back files, develop born-digital serials, adapt cataloging guidelines to electronic full-text journals, and evaluate the completeness of full-text journals that often omitted graphics and other materials. During the same period, libraries were beginning to grapple with ways to select, organize, and improve access to Internet resources. Creating web pages dominated the 1998 conference, with eleven presentations giving serialists opportunities to learn new skills for using the web. Presentations at that conference also revealed a growing awareness that electronic serials might not be the answer to the serials crisis, with presenters discussing pricing models and the costs of hosting and supporting e-journals. Conference-goers who chose to attend the concurrent session "STM X-REF: A Link Service for Publishers and Readers" would have heard an early proposal for a linking service that would help users connect citations with the full-text article across databases; ${ }^{34}$ linking services were discussed as a reality in 2002.

In her review of the serials literature of 2002, Silva commented that while networked information and electronic publishing had dominated the serials literature in 1992, a decade later every aspect of serials from cataloging to preservation included issues relating to electronic serials and their access. ${ }^{35}$ The NASIG conferences also reflected the increasing pervasiveness of electronic serials in all aspects of serials work. As the twenty-first century began, NASIG 
presenters increasingly discussed technology as one aspect of other topics, rather than as the focus of their presentations. OpenURLs, linking services, and staff restructuring were discussed at NASIG between 2001 and 2005, just as they were in the serials journal literature. ${ }^{36}$ but the peak years for technology-focused presentations had passed. Blessinger and Frasier also found in their study of the 1994-2004 literature that the topic of automation peaked in 1997 and then made a drastic decline with other technology topics becoming more prevalent. ${ }^{37}$

\section{Serials Industry}

The serials industry itself was the second most frequently discussed topic at the first twenty NASIG conferences; activities of publishers, vendors, and subscription agents was a major or predominant topic for $21.5 \%$ of the presentations. The attention paid to the serials industry varied from conference to conference, but at least one presentation at every conference focused on the serials industry. As can be seen in Figure 3, this topic fits Atkin's stable classification because it was regularly discussed with few fluctuations. ${ }^{38}$ Serials industry was the most frequently assigned topic in 1987 and 2004.

\section{[Insert Figure 3]}

From its inception, NASIG has focused on helping all the players in the serials chain understand each other's roles and perspectives. The first conference included two presentations on British journal pricing, one by a publisher and the other by a subscription agent. In 1987, presentations on Journal Citation Reports offered insights into the relationships between journal publishers, secondary publishers, and librarians. These paired presentations offering different perspectives on a common issue or concern became a staple at NASIG.

Many of the serials industry presentations discussed projects with several players in the serials chain working together to improve services or provide information in new ways. As with 
NASIG presentations, the literature also showed the concern about the relationships between librarians and the publishing industry. The literature between 1986 and 1990 continued to be dominated by discussions of serials pricing, with a variety of articles about the publishing process itself. There were also a number of articles written by and about subscription agents discussing the roles and expectations of both librarian and agent. ${ }^{39,40,41,42,43}$ Between 1990 and 1996, common topics at the conferences included cooperative efforts to develop serials control systems, pilot projects with EDI renewals and invoicing, and developing standards to make automated/electronic serials communication feasible. A 1993 presentation focusing on the Red Sage Project discussed the collaboration between the University of California San Francisco, AT\&T Bell Labs, and Springer-Verlag to digitize selected titles in health sciences; testing production methods and exploring how these electronic journals met researchers' needs. ${ }^{44}$ Collaborative efforts to develop electronic full-text journal collections were frequently discussed in the mid-1990s. As electronic journals developed and Internet access became more common, presentations on the changing roles of subscription agents and on licensing of electronic resources to consortia proliferated in the mid-to-late 1990s.

At the turn of the century, topics at NASIG presentations paralleled those in the serials literature. Corbett noted that the serials literature showed a movement toward finding solutions to the problems posed by increases in the journal literature and journal prices, and increasing concern about who should archive electronic journals. ${ }^{45}$ At NASIG, the perspectives of publishers, aggregators, and libraries were discussed as considerations in developing acceptable pricing models for electronic journal packages. Attendees were challenged to continue supporting small publishers despite the temptation of large journal packages, and encouraged to support alternative publishing initiatives. While some presentations questioned whether 
subscriptions agents are needed when libraries are increasingly subscribing to e-journal packages, others pointed out new services that agents offer to help manage electronic journals. Presentations at the 2004 and 2005 conferences showed that collaboration among publishers, vendors, agents, and libraries is still vibrant, with presentations such as the establishment of electronic archiving services in lieu of libraries or publishers individually archiving e-resources, and the development of standards for reporting usage data for electronic resources.

\section{Serials Management}

Managing serials in libraries through activities such as check-in, processing, serials control, authentication, and license management was discussed in $20 \%$ of the presentations, making it the third most frequently discussed topic. As shown in Figure 4, this topic fits Atkin's roller coaster classification because its popularity rose, fell, and rose again. ${ }^{46}$ Serials management was discussed at every conference except the first three, but in 1994 and 1995, no presentations were predominantly about serials management. In recent years, serials management gained in popularity; it tied with technology for most frequently discussed topic in 2003 and was the most frequently discussed topic in 2005.

\section{[Insert Figure 4]}

During the early conferences, 1986-1990, presentations focused on managing print serials using new automated systems for check-in and binding. Stankus commented that the serials literature of 1987 showed a number of articles dealing with serials automation with the trend toward migrating to stand-alone micro based workstations rather than mainframe-based systems, especially in special libraries. ${ }^{47}$ As Davis noted, the serials literature of 1988 and 1989 included many descriptions of automating serials control systems. ${ }^{48,49}$ During the 1991 to 1993 NASIG conferences, a half dozen presentations reveal how serials managers struggled to fine-tune the 
claiming process after automation made it possible to produce claims so easily that the volume of claims became overwhelming.

Presentations on serials management became more common as NASIG's second decade began. Although e-journals were being discussed at NASIG as early as 1988, it was 1996 before e-journal management was discussed at any length in a presentation. From 1997 to 1999 , sessions on team projects and collaboration between library units reflected new challenges in managing e-journals and web resources. Several sessions in 2000 and 2001 focused on how various libraries tackled the problem of providing patron access to e-journals through online ejournal lists and links in MARC records. Serials managers were also struggling to manage licensing information; the 2002 and 2003 conferences each included two sessions that discussed locally developed or commercial electronic resource management systems (ERMS). The challenges of managing electronic subscriptions were also heavily discussed in the serials literature between 2000 and 2003; Corbett commented that many articles discussed the development of home-grown databases to track and share e-journal license terms and of commercial products to help librarians track titles in packages, title changes, and URLs

efficiently. ${ }^{50}$ A variety of e-journal management issues, from maintaining a link resolver to resolving license breaches, were discussed in 2004 and 2005, with a few sessions on print journals and other management issues.

\section{Scholarly Information Issues}

The fourth most frequently discussed topic at NASIG, scholarly information issues, includes copyright and other intellectual property rights, the scholarly communication process including peer review and the impact of tenure requirements on scholarly communication, and initiatives to change scholarly communication such as open access and institutional repositories. 
As can be seen in Figure 5, this topic fits Atkin's stable classification because it was regularly discussed with few fluctuations. ${ }^{51}$ NASIG conference planners apparently considered scholarly information issues to be important to all serialists since $25 \%$ of the vision sessions, which are intended to appeal to all NASIG attendees, discussed this topic.

\section{[Insert Figure 5]}

Copyright has been a recurring issue at NASIG. As hard as it is to imagine photocopiers being a major concern today, the 1988 conference included five sessions on dealing with the copyright issues presented by photocopier use in libraries, especially for interlibrary loan. While NASIG presenters were discussing the copyright issue at the 1988 conference, the authors found that of the articles examined, Davis was the first to mention copyright in her 1989 review of the literature. There were several papers written on various aspects of copyright, including the effects that these new technologies will have on copyright law. ${ }^{52}$ The copyright issues posed by electronic publications were discussed several times between 1992 and 1996. New laws dealing with copyright in the digital environment were discussed between 2000 and 2003.

The scholarly communication process has also been a frequent issue, but it was particularly strong in the 1990s. Peer review was the hot topic of 1990 , with five presentations on various aspects of peer review. Several sessions during the 1990s examined the history and development of the journal as the predominant mode of communicating scientific discoveries. A few presentations discussed how pressure to publish in order to achieve tenure fueled the rapid expansion of journals in the twentieth century, while others discussed the shift from journal publishing as primarily a scholarly society service activity to an increasingly commercial industry. Many presentations in the 1990s focused on the potential for digital technologies to transform scholarly communication by making it feasible for scholars to share large data sets 
globally, incorporate multimedia in journal articles, and share discoveries quickly through online pre-print databases.

Concerns about the sustainability of scholarly publishing led to interest in alternative publishing models as the twenty-first century began. Alternatives to commercial publishing became a hot topic in 2001, with presentations on the BioOne alliance to make bioscience journals published by not-for-profit organizations available digitally, PubMed Central's biomedical and life science digital archive, and the Scholarly Publishing and Academic Resources Coalition's (SPARC) efforts to promote alternative publication models through education and incubator projects. As Corbett noted, scholarly communication was changing and the library literature was replete with articles on the different group-based efforts to open up the

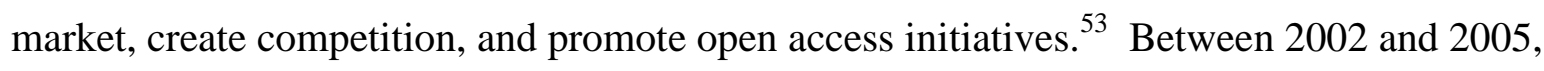
alternative publishing models continued to be discussed, along with presentations on how to encourage scholars to participate in institutional repositories. But serialists were also expressing concern about the impact of digital publishing on scholarly communication, as evidenced by presentations on the potential to lose information if more attention was not paid to archiving digital publications, and on the changing patterns of information use that were becoming apparent as libraries subscribed to large packages of electronic journals.

\section{Other Frequently Assigned Categories}

Three other categories, collection development, bibliographic control, and professional issues and skills were each assigned to slightly more than $10 \%$ of the NASIG presentations (see Table 3). Collection development, which the authors defined as selecting, evaluating, and deselecting information resources, was discussed in $11 \%$ of the presentations. From 1986 to 1996, most collection development presentations focused on managing tight budgets, conducting 
price studies, evaluating use, and implementing serial review projects with a slight leavening of other topics such as the challenges of collecting foreign serials. The focus shifted during the 1987 conference, with several presentations on collecting electronic resources, as well as discussions of relying on consortia and document delivery instead of attempting to collect serials for every need. A new collection development problem emerged with the 1999 conference, the question of how to develop and evaluate collections with the advent of e-journal aggregations and large consortial purchases of e-journal packages. By 2000, the familiar topics of evaluating use and implementing serial review projects were back, with discussions of collecting usage data for e-journals and seeking faculty input on serials in an era of journal packages. The 2003 conference included several presentations on the advantages and disadvantages of big deal ejournal packages. Concerns about usage data and evaluating e-journal packages continued to be discussed through the 2005 conference. The serials literature also followed what the NASIG presentations were discussing. During the late 1980's and into the 1990's the literature focused on rising journal costs, price studies as an evaluation tool, and cancellation projects. The twentyfirst century was all about electronic journals, bundled packages, serials pricing, collecting usage statistics, and print versus electronic collections. Collection management was focusing on format selection and the trend of cancelling print subscriptions in favor of electronic access brought about by flat library budgets and the rising costs of electronic resources.

Bibliographic control, which the authors defined as providing access to information through activities such as cataloging, A-Z list creation, and metadata creation, was discussed in $10.7 \%$ of the presentations. Presentations from 1986 to 1992 ran the gamut from cataloging in an automated environment to dealing with title changes. Beginning in 1992, NASIG conference presentations clearly reflect the impact of the new electronic serials on catalogers, as multiple 
presentations discussed whether to apply the computer file rules, serials rules, or some unauthorized hybrid when cataloging computer files that accompanied serials or serials that were issued in electronic format. The serials literature during this time seemed to follow the topics that NASIG presentations were discussing. According to Williams in his review of the literature 1991-1996, the cataloging of electronic journals emerged as a new topic. Much of the literature during this time focused on serials cataloging, rule interpretations, and format integration. ${ }^{54}$ Although the interim guidelines for cataloging serial computer files were a hot topic at the 1997 conference, attention began shifting toward metadata and dealing with e-journal aggregations in the late 1990s as libraries tried to work out methods for providing access to growing collections of electronic resources. At the turn of the century, topics of discussion included extracting data from MARC records to create hyperlinked A-Z lists of e-journals, revisions in the serials cataloging rules in AACR2, and projects to create metadata for consortial and statewide serial collections. Copeland stated, "Toward the latter half of the decade, discussions of metadata as an alternative to full MARC cataloging for e-resources, and OCLC's CORC project in particular, swell in the literature." 55 The 2005 presentations on FRBR, metadata, and AACR3 all suggest that changing principles and practices for bibliographic control of serials will remain a topic of interest at NASIG in the future.

Although professional issues and skills were discussed in $10.1 \%$ of the NASIG presentations, these offerings were rare prior to 1992. The authors defined this category to include career development topics such as education for librarianship, alternative careers, time management, presentation and web design skills. Topics discussed during the first six conferences included education for serials work, alternative careers for serials librarians, and interpreting job descriptions. Presentations on professional issues and skills jumped in 1992, with 
sessions on delivering workshops, publishing, and basic serials knowledge for librarians new to serials. The 1994 conference was another strong year for this category, in addition to sessions on job hunting, new roles for librarians, and management skills, there were three sessions to help serialists develop skills in using new technology tools, such as gophers. Several presentations each year from 1995 to 1997 focused on professional issues and skills with topics ranging from working with library schools to prepare future serialists to using the World Wide Web in serials work. The 1998 conference included several preconference sessions devoted to web development skills, making it the peak year for this category. After the 1998 peak, the category stabilized with three or four presentations a year on topics ranging from strategies for managing work relationships to succeeding in a tenure-track position. According to Blessinger and Frasier's study, they also found that the literature between 1994 and 2004 was heavy with professional issues such as relationships with faculty, status of librarians, philosophical aspects of the profession, and careers within librarianship. ${ }^{56}$

\section{Infrequently Assigned Categories}

Economics of information was discussed at every NASIG conference from 1986 to 2005

(see Table 4). During NASIG's first decade, presentations on serials prices, price studies, and the impact of rapidly rising prices on library budgets were common, but those same years also saw a number of presentations about the costs of editing, producing, and marketing serials. Other topics included subscription agent service charges, the impact of exchange rate and currency fluctuations on prices and budgets, and the challenges of forecasting prices to plan budgets. During the mid-1990s, several presentations discussed analyzing the cost effectiveness of document delivery and interlibrary loan. Although many presentations about developing electronic serials had mentioned costs, the 1998 conference was notable for the extent to which 
the economic impact of electronic publishing was discussed. Seven presentations on the topic considered publishing costs, cost of technology in libraries, pricing models for e-journals, and the possibility that technology might not make serials less expensive. Pricing models for consortial subscriptions, potential cost savings from alternative publishing models, and the relationship between publisher consolidation and pricing were all discussed between 2000 and 2005 , with a few presentations on the cost of editing and producing journals.

Presentations on workflow and staffing have been another staple of NASIG conferences, with every conference including presentations on some aspect of designing workflows or selecting and training staff. Many presentations dealt with very specific problems, such as how to train staff to interpret serials records or establish an effective claiming workflow. The 1994 conference, however, was notable because two vision sessions about managing change focused attention on workflow and staffing issues; other sessions discussed strategies for communicating change, understanding how individuals perceive change, and several case studies of workflow changes. During the mid-to-late 1990s, several presentations discussed the use of teams in managing serials and motivating staff. As electronic serials became increasingly common in the early twenty-first century, changing staffing needs began being discussed, but the peak years of workflow and staffing presentations had passed.

A number of presentations were coded to the users and public services category, which the authors defined as "discussions of end users and public service activities, including generational issues and changing expectations." Sessions focusing on users and public services were rare during the first decade of NASIG conferences, but increased during NASIG's second decade. Presentations in this category discuss a wide range of topics, including public service staff involvement with serials teams, the need to plan for future users in making collection and 
preservation decisions, and teaching faculty to access serials in new formats. In recent years, several presentations have discussed what analysis of e-journal usage statistics reveals about how various groups use journals; as standards for reporting usage are implemented, interest in this topic is likely to grow.

Standards development was discussed at all but two of the first twenty conferences demonstrating the importance of standards to serialists. This category includes the development and revision of all types of standards, from cataloging standards like AACR2 to standards for serial identifiers like SISAC barcodes. While standards may seem a dry and difficult topic with a plethora of acronyms, the NASIG presentations demonstrate their importance in acquiring serials, requesting serial articles through interlibrary loan, and providing access via online catalogs and link resolvers. Many presentations discuss developing standards to facilitate communication among publishers, subscription agents, automation system vendors, libraries, and others in the serials information chain. Standards may never be a hot topic at NASIG, but the 2005 presentations on standards for usage statistics, article-level identifiers, and major revisions to the Anglo-American Cataloging Rules suggest that standards development will continue to be discussed because they impact many areas of serials work.

Two categories, resource sharing and acquisitions, were discussed at most of the conferences, but with distinct shifts in topics between the first and second decade of NASIG. During the first decade, the resource sharing presentations discussed union lists, document delivery, and interlibrary loan activities. The acquisitions presentations focused on automating ordering and invoicing activities and selecting vendors. As NASIG's second decade began, the increasing availability of electronic serials was reflected in both categories by a shift toward discussing licensing issues. The resource sharing presentations reflect growing interest in 
forming consortia to share electronic resources, while the acquisitions presentations focused on negotiating licenses. As NASIG's second decade ended, several presentations signaled possible topic shifts in the two categories. In 2003, the new resource sharing topic was cooperative archives and repositories. In 2004, acquisitions presentations included licensing terms, efficient serial acquisition workflows, and vendor relations.

The remaining three topics, future of serials, preservation and perpetual access, and access versus ownership, reflected distinct periods of interest and disinterest. Thirty-two out of the thirty-nine presentations that discussed predictions about serials and their role in scholarly communication were made at the nine conferences from 1992 to 2000 (see Table 4). Presenters made predictions ranging from the possibility that journals might disappear as the Internet makes article-level publishing feasible to the potential benefits of enriching journals with multimedia and links to extensive data sets. While some serialists were considering the future, others were discussing preservation and perpetual access, which includes activities like archiving, disaster preparedness, binding, and planning for perpetual access. More than half of the presentations about preservation and perpetual access were made at the four conferences from 1997 to 2000. While the number of presentations declined after 2000, every conference from 2001 to 2005 included at least one discussion of preservation and perpetual access, suggesting the topic may be a staple at future NASIG conferences. The final topic, coded to only twenty-five presentations, was access versus ownership. The authors defined access versus ownership narrowly as discussions of philosophical, financial, legal, and other issues of deciding whether to purchase materials or provide access to materials through licensing agreements and resource sharing arrangements. The first year it was discussed, 1992, was also the peak year for presentations about access versus ownership; the topic was discussed at every conference from 
1992 to 2002, then disappeared completely from NASIG presentations, possibly signaling acceptance of the impossibility for any library to purchase all the resources it needs.

\section{Conclusion and Suggestions for Future Research}

This analysis of NASIG presentations has revealed the major issues, trends, and developments in the serials world between 1986 and 2005. The NASIG proceedings serve as a snapshot of what was and continues to be important to serialists.

Three of the questions that guided this research centered on the frequency, popularity, and emphasis of topics discussed at NASIG. Over NASIG's first 20 years, technology impact, serials industry, serials management, and scholarly information issues have consistently been the most frequently discussed topics. The popularity of these topics has changed from year to year. For example, technology impact was the most popular topic at all but four conferences; however the emphasis on technology shifted as it was integrated into all aspects of the serials information chain. It has changed workflows and influenced the development of standards and practices, as well as creating the need for additional training and professional development for those in both technical services and public services. Technology impact was in the forefront while automation, the Internet, and electronic resources were new, but it is slipping to the background as technology becomes a common tool.

The fourth research question asked whether some topics are frequently discussed together

during NASIG presentations. By computing correlations between topics the authors discovered that only a few topics are frequently discussed together.

The fifth question, whether the topics discussed at NASIG reflected trends discussed in the serials literature, was challenging to research. The authors located reviews of the serials literature for 1986 through 1993 and for 2000-2003, but could not locate reviews for the mid to 
late 1990s. Another challenge was that topics have not been defined consistently in serials literature. For example, the authors considered use studies and cancellation projects to be part of collection development, while many of the literature reviews lumped discussions of use and cancellation projects in with serials management. However, it does appear that the topics discussed at NASIG reflect the trends in the serials literature.

As others have commented, and this analysis confirms, serials professionals tend to be more concerned with finding solutions to practical issues that face the profession rather than with the theoretical and philosophical aspects of library and information science. While NASIG's vision sessions encourage reflection on theory and philosophy, most conference sessions focus on the practical issues.

This study has generated some ideas for further research. An analysis of NASIG presenters and their organizations might identify those which tend to be change agents in the serials community. Perhaps a comparison of individuals who report NASIG sessions, present at NASIG, serve as NASIG officers, and publish peer-reviewed literature about serials would reveal career development patterns and help predict those who are likely to become leaders in the serials world. Content analysis of other conference proceedings might also be useful in discovering trends in areas related to serials. 


\section{Notes}

1. About NASIG, "NASIG and You!" http://www.nasig.org/public/AboutNASIG.htm (accessed July 18, 2007).

2. Klaus Krippendorff, Content Analysis: An Introduction to Its Methodology (Thousand Oaks, CA: Sage Publications, 2004), 18.

3. Marilyn Domas White and Emily E. Marsh, "Content Analysis: A Flexible Methodology," Library Trends 55 (Summer 2006): 22-45.

4. Kelly Blessinger and Michele Frasier, "Analysis of a Decade in Library Literature: 19942004, College \& Research Libraries 68 (March 2007): 155-69.

5. Bryce Allen, “Content Analysis in Library and Information Science Research,” Library \& Information Science Research 12 (July-September 1990): 251-62.

6. Lois Buttlar, "Analyzing the Library Periodical Literature: Content and Authorship," College \& Research Libraries 52 (January 1991): 38-53.

7. John C. Rowley, "The Conference Literature: Savory or Acrid?” in Conference Literature, its Role in the Distribution of Information: Proceedings of the Workshop on Conference Literature in Science and Technology May 1-3, 1980, ed., Gloria J. Zamora (Marlton, N.J.: Learned Information, 1981): 11-20.

8. Stephen E. Atkins, "Subject Trends in Library and Information Science Research, 1975 1984.” Library Trends 36 (Spring 1988): 633-58.

9. Buttlar, "Analyzing the Library Periodical Literature," 38-53.

10. Kalervo Jarvelin and Prtti Vakkari, "Content Analysis of Research Articles in Library and Information Science," Library \& Information Science Research 12 (October-December 
1990): 395-421.

11. Leif Kajberg, “A Content Analysis of Library \& Information Science Serial Literature Published in Denmark, 1957-1986, ” Library \& Information Science Research 18 (1996): 25-52.

12. Tony Stankus, “The Year's Work in Serials, 1986," Library Resources \& Technical Services 31 (October/December 1987): 306-20.

13. Tony Stankus, “The Year's Work in Serials, 1987," Library Resources \& Technica Services 32 (July 1988): 217-32.

14. Susan Davis, “The Year's Work in Serials, 1988, " Library Resources \& Technical Services 33 (July 1989): 227-39.

15. Susan Davis, “The Year's Work in Serials, 1989," Library Resources \& Technical Service 34 (July 1990): 313-25.

16. Jana Lonberger, “The Rise in Consumerism: The Year's Work in Serials, 1990,” Library Resources \& Technical Services 35 (July 1991): 319-31.

17. John J. Riemer, “A Rising Sense of Urgency: The Year's Work in Serials, 1991, Library Resources \& Technical Services 36 (July 1992): 361-73.

18. John F. Riddick, “An Electrifying Year: A Year’s Work in Serials, 1992, Library Resources \& Technical Services 37 (July 1993): 335-342.

19. Denise P. Kaplan, “The Year's Work in Technical Services Automation, 1989, ” Library Resources \& Technical Services 34 (July 1990): 299-313.

20. James W. Williams, “Serials Cataloging, 1991-1996: A Review,” Serials Librarian, 32, no. 1/2 (1997): 3-26.

21. Ann Copeland, "E-Serials Cataloging in the 1990s: A Review of the Literature," Serials 
Librarian 41, no. 3/4 (2002): 7-29.

22. Judith L Silva, “A Leap into the Future: Serials Literature of 2002," Serials Review 30 (November 2004): 33-41.

23. Lauren E. Corbett, "Serials Review of the Literature 2000-2003," Library Resources \& Technical Services 50 (January 2006): 16-30.

24. Skymeg Software. "PRAM: a Program for Reliability Assessment with Multiple Coders," http://www.geocities.com/skymegsoftware/pram.html (Accessed November 5, 2007).

25. Kimberly A. Neuendorf, The Content Analysis Guidebook (Thousand Oaks: CA: Sage Publications, 2002), 143.

26. Denise Novak, e-mail to Liblicense mailing list, July 5, 2007, http://www.library.yale.edu/ 1license/ListArchives/0707/msg00035.html (Accessed October 15, 2007).

27. Ibid.

28. Atkins, "Subject Trends in Library and Information Science Research," 651.

29. Stankus, “The Year's Work in Serials, 1986," 306-20.

30. Davis, “The Year's Work in Serials, 1988," 227-39.

31. Davis, “The Year's Work in Serials, 1989," 313-25.

32. Copeland, "E-Serials Cataloging in the 1990s," 7-29.

33. Blessinger and Frasier, "Analysis of a Decade in Library Literature,” 159.

34. Gerry Grenier, "STM-X-Ref: A Link Service for Publishers and Readers," Serials Librarian 36, no. 1/2 (1999): 175-85.

35. Silva, “A Leap into the Future: Serials Literature of 2002,” 33-41.

36. Corbett, "Serials Review of the Literature 2000-2003," 16-30. 
37. Blessinger and Frasier, "Analysis of a Decade in Library Literature," 155-69.

38. Atkins, "Subject Trends in Library and Information Science Research," 650.

39. Stankus, "The Year's Work in Serials, 1986," 306-20.

40. Stankus, "The Year's Work in Serials, 1987," 217-32.

41. Davis, "The Year's Work in Serials, 1988," 227-39.

42. Davis, "The Year's Work in Serials, 1989," 313-25.

43. Lonberger, "The Rise in Consumerism," 319-31.

44. E. R. Lucier, et al., "Red Sage Project," Serials Librarian 24, no. 3/4 (1994): 129-34.

45. Corbett, "Serials Review of the Literature 2000-2003," 16-30.

46. Atkins, "Subject Trends in Library and Information Science Research," 643.

47. Stankus, "The Year's Work in Serials, 1987," 217-32.

48. Davis, "The Year's Work in Serials, 1988,” 227-39.

49. Davis, "The Year's Work in Serials, 1989," 313-25.

50. Corbett, "Serials Review of the Literature 2000-2003," 16-30.

51. Atkins, "Subject Trends in Library and Information Science Research," 650.

52. Davis, “The Year's Work in Serials, 1989," 313-25.

53. Corbett, "Serials Review of the Literature 2000-2003," 16-30.

54. Williams, "Serials Cataloging, 1991-1996," 3-26.

55. Copeland, "E-Serials Cataloging in the 1990s," 21.

56. Blessinger and Frasier, "Analysis of a Decade in Library Literature," 155-69. 
Table 1. Presentations by type and year

\begin{tabular}{lrrrrrrrrrrrrrrrrrrrrr}
\hline Type & 86 & 87 & 88 & 89 & 90 & 91 & 92 & 93 & 94 & 95 & 96 & 97 & 98 & 99 & 00 & 01 & 02 & 03 & 04 & 05 & Total \\
\hline Pre-con & 0 & 0 & 0 & 0 & 0 & 0 & 2 & 1 & 2 & 0 & 7 & 5 & 11 & 4 & 3 & 2 & 2 & 2 & 3 & 3 & 47 \\
Paper/Panel & 15 & 12 & 13 & 14 & 15 & 0 & 0 & 0 & 0 & 0 & 0 & 0 & 0 & 0 & 0 & 0 & 0 & 0 & 0 & 0 & 69 \\
Vision & 0 & 0 & 0 & 1 & 0 & 9 & 8 & 8 & 8 & 6 & 6 & 3 & 3 & 3 & 3 & 3 & 3 & 3 & 4 & 2 & 73 \\
Strategy & 0 & 0 & 0 & 0 & 0 & 0 & 12 & 11 & 15 & 18 & 13 & 16 & 20 & 19 & 9 & 8 & 9 & 13 & 12 & 12 & 187 \\
Tactics & 5 & 6 & 8 & 11 & 18 & 18 & 17 & 19 & 18 & 20 & 20 & 22 & 20 & 22 & 32 & 24 & 26 & 23 & 15 & 18 & 362 \\
$\quad$ TOTAL & 20 & 18 & 21 & 26 & 33 & 27 & 39 & 39 & 43 & 44 & 46 & 46 & 54 & 48 & 47 & 37 & 40 & 41 & 34 & 35 & 738 \\
\hline
\end{tabular}

Note: Presentation types are listed by their current names. Vision includes plenaries and keynotes. Strategy includes issues, projects, and concurrents. Tactics include workshops.

Table 2. Presentations by number of categories

assigned

\begin{tabular}{rr}
\hline $\begin{array}{r}\text { No. of } \\
\text { categories } \\
\text { assigned }\end{array}$ & $\begin{array}{r}\text { No. of } \\
\text { presentations }\end{array}$ \\
\hline 0 & 1 \\
1 & 241 \\
2 & 327 \\
3 & 135 \\
4 & 33 \\
5 & 1 \\
Total & 738 \\
\hline
\end{tabular}


Table 3. Categories ranked by frequency assigned

\begin{tabular}{lrr} 
& $\begin{array}{l}\text { Number of } \\
\text { presentations } \\
\text { to which } \\
\text { assigned } \\
N=1437\end{array}$ & $\begin{array}{l}\text { Percentage of } \\
\text { presentations } \\
\text { to which } \\
\text { assigned } \\
N=738\end{array}$ \\
Category & 353 & 47.8 \\
\hline Technology impact & 159 & 21.5 \\
Serials industry & 148 & 20.1 \\
Serials management & 100 & 13.6 \\
Scholarly information issues & 81 & 11.0 \\
Collection development & 79 & 10.7 \\
Bibliographic control & 75 & 10.2 \\
Professional issues and skills & 71 & 9.6 \\
Economics of information & 65 & 8.8 \\
Workflow and staffing & 61 & 8.3 \\
Users and public services & 60 & 8.1 \\
Standards development & 50 & 6.8 \\
Resource sharing & 40 & 5.4 \\
Acquisitions & 39 & 5.3 \\
Future of serials & & \\
Preservation and perpetual & 31 & 4.2 \\
access & 25 & 3.4 \\
Access vs. ownership & &
\end{tabular}


Table 4. Categories assigned by year

\begin{tabular}{|c|c|c|c|c|c|c|c|c|c|c|c|c|c|c|c|c|c|c|c|c|c|c|}
\hline Categories & & 86 & 87 & 88 & 89 & 90 & 91 & 92 & 93 & 94 & 95 & 96 & 97 & 98 & 99 & 00 & 01 & 02 & 03 & 04 & 05 & Total \\
\hline \multicolumn{23}{|c|}{ Access vs. ownership } \\
\hline Predominant & & 0 & 0 & 0 & 0 & 0 & 0 & 3 & 1 & 2 & 0 & 0 & 0 & 0 & 3 & 0 & 1 & 1 & 0 & 0 & 0 & 11 \\
\hline \multirow[t]{2}{*}{ Major } & & 0 & 0 & 0 & 0 & 0 & 0 & 4 & 0 & 0 & 1 & 1 & 2 & 1 & 1 & 2 & 2 & 0 & 0 & 0 & 0 & 14 \\
\hline & Total & 0 & 0 & 0 & 0 & 0 & 0 & 7 & 1 & 2 & 1 & 1 & 2 & 1 & 4 & 2 & 3 & 1 & 0 & 0 & 0 & 25 \\
\hline \multicolumn{23}{|l|}{ Acquisitions } \\
\hline Predominant & & 0 & 2 & 1 & 1 & 0 & 1 & 1 & 2 & 1 & 0 & 1 & 3 & 0 & 1 & 0 & 5 & 0 & 0 & 3 & 0 & 22 \\
\hline \multirow[t]{2}{*}{ Major } & & 0 & 0 & 0 & 3 & 2 & 1 & 2 & 0 & 1 & 1 & 0 & 0 & 0 & 1 & 1 & 0 & 1 & 2 & 3 & 0 & 18 \\
\hline & Total & 0 & 2 & 1 & 4 & 2 & 2 & 3 & 2 & 2 & 1 & 1 & 3 & 0 & 2 & 1 & 5 & 1 & 2 & 6 & 0 & 40 \\
\hline \multicolumn{23}{|c|}{ Bibliographic control } \\
\hline Predominant & & 1 & 0 & 2 & 2 & 2 & 0 & 3 & 5 & 5 & 5 & 3 & 6 & 2 & 5 & 7 & 1 & 7 & 4 & 2 & 4 & 66 \\
\hline \multirow[t]{2}{*}{ Major } & & 1 & 0 & 0 & 0 & 1 & 2 & 0 & 0 & 0 & 2 & 0 & 3 & 1 & 0 & 0 & 0 & 0 & 2 & 1 & 0 & 13 \\
\hline & Total & 2 & 0 & 2 & 2 & 3 & 2 & 3 & 5 & 5 & 7 & 3 & 9 & 3 & 5 & 7 & 1 & 7 & 6 & 3 & 4 & 79 \\
\hline \multicolumn{23}{|c|}{ Collection development } \\
\hline Predominant & & 1 & 1 & 0 & 2 & 3 & 0 & 1 & 3 & 1 & 2 & 2 & 2 & 4 & 4 & 5 & 2 & 4 & 5 & 5 & 6 & 53 \\
\hline \multirow[t]{2}{*}{ Major } & & 0 & 0 & 2 & 0 & 0 & 2 & 4 & 1 & 0 & 1 & 2 & 7 & 1 & 4 & 0 & 0 & 1 & 1 & 1 & 1 & 28 \\
\hline & Total & 1 & 1 & 2 & 2 & 3 & 2 & 5 & 4 & 1 & 3 & 4 & 9 & 5 & 8 & 5 & 2 & 5 & 6 & 6 & 7 & 81 \\
\hline \multicolumn{23}{|c|}{ Economics of information } \\
\hline Predominant & & 5 & 4 & 3 & 5 & 4 & 2 & 2 & 1 & 1 & 0 & 1 & 1 & 4 & 3 & 1 & 1 & 3 & 0 & 4 & 1 & 46 \\
\hline \multirow[t]{2}{*}{ Major } & & 0 & 0 & 0 & 1 & 1 & 2 & 2 & 0 & 1 & 2 & 1 & 3 & 3 & 0 & 3 & 0 & 0 & 1 & 3 & 2 & 25 \\
\hline & Total & 5 & 4 & 3 & 6 & 5 & 4 & 4 & 1 & 2 & 2 & 2 & 4 & 7 & 3 & 4 & 1 & 3 & 1 & 7 & 3 & 71 \\
\hline \multicolumn{23}{|l|}{ Future of serials } \\
\hline Predominant & & 1 & 0 & 0 & 0 & 1 & 0 & 1 & 4 & 1 & 2 & 1 & 2 & 0 & 1 & 2 & 0 & 0 & 0 & 0 & 0 & 16 \\
\hline \multirow[t]{2}{*}{ Major } & & 0 & 0 & 0 & 0 & 1 & 0 & 3 & 3 & 3 & 1 & 3 & 1 & 1 & 1 & 2 & 0 & 1 & 1 & 1 & 1 & 23 \\
\hline & Total & 1 & 0 & 0 & 0 & 2 & 0 & 4 & 7 & 4 & 3 & 4 & 3 & 1 & 2 & 4 & 0 & 1 & 1 & 1 & 1 & 39 \\
\hline \multicolumn{23}{|c|}{ Preservation and perpetual access } \\
\hline Predominant & & 0 & 0 & 0 & 1 & 1 & 1 & 0 & 0 & 0 & 1 & 0 & 5 & 2 & 1 & 5 & 0 & 1 & 3 & 1 & 0 & 22 \\
\hline \multirow{2}{*}{ Major } & & 0 & 0 & 0 & 0 & 0 & 0 & 1 & 0 & 0 & 0 & 0 & 0 & 2 & 1 & 2 & 1 & 1 & 0 & 0 & 1 & 9 \\
\hline & Total & 0 & 0 & 0 & 1 & 1 & 1 & 1 & 0 & 0 & 1 & 0 & 5 & 4 & 2 & 7 & 1 & 2 & 3 & 1 & 1 & 31 \\
\hline \multicolumn{23}{|c|}{ Professional issues and skills } \\
\hline Predominant & & 1 & 1 & 1 & 1 & 0 & 1 & 3 & 0 & 5 & 4 & 2 & 0 & 3 & 4 & 3 & 5 & 3 & 4 & 3 & 4 & 48 \\
\hline \multirow[t]{2}{*}{ Major } & & 0 & 0 & 0 & 0 & 0 & 0 & 2 & 1 & 3 & 1 & 2 & 4 & 10 & 2 & 0 & 0 & 0 & 1 & 0 & 1 & 27 \\
\hline & Total & 1 & 1 & 1 & 1 & 0 & 1 & 5 & 1 & 8 & 5 & 4 & 4 & 13 & 6 & 3 & 5 & 3 & 5 & 3 & 5 & 75 \\
\hline \multicolumn{23}{|c|}{ Resource sharing } \\
\hline Predominant & & 0 & 1 & 1 & 1 & 3 & 0 & 3 & 2 & 1 & 1 & 4 & 2 & 4 & 2 & 3 & 3 & 1 & 2 & 0 & 0 & 34 \\
\hline Major & & 0 & 0 & 2 & 0 & 0 & 0 & 1 & 0 & 0 & 3 & 0 & 1 & 0 & 2 & 2 & 2 & 0 & 2 & 1 & 0 & 16 \\
\hline & Total & 0 & 1 & 3 & 1 & 3 & 0 & 4 & 2 & 1 & 4 & 4 & 3 & 4 & 4 & 5 & 5 & 1 & 4 & 1 & 0 & 50 \\
\hline Scholarly inforr & issues & & & & & & & & & & & & & & & & & & & & & \\
\hline Predominant & & 0 & 1 & 6 & 4 & 6 & 4 & 6 & 4 & 3 & 8 & 6 & 3 & 1 & 2 & 5 & 3 & 8 & 1 & 3 & 3 & 77 \\
\hline Major & & 0 & 0 & 0 & 0 & 0 & 1 & 2 & 5 & 1 & 0 & 2 & 0 & 1 & 1 & 2 & 2 & 0 & 3 & 3 & 0 & 23 \\
\hline & Total & 0 & 1 & 6 & 4 & 6 & 5 & 8 & 9 & 4 & 8 & 8 & 3 & 2 & 3 & 7 & 5 & 8 & 4 & 6 & 3 & 100 \\
\hline
\end{tabular}


Serials industry

Predominant

Major

Serials management

Predominant

Major

Tor

$\begin{array}{lll}2 & 7 & 3 \\ 1 & 0 & 2 \\ 3 & 7 & 5\end{array}$

5
2
7

3
4
7

Standards development

Predominant

Major

Total

Technology impact

Predominant

Major

$\begin{array}{rr} & \\ & 9 \\ & 1 \\ \text { Total } & 10\end{array}$

Users and public services

Predominant

Major

Total

Workflow and staffing

Predominant

Major

All presentations

Presentations

Topics Assigned

$\begin{array}{ll}0 & 1 \\ 1 & 2 \\ 1 & 3\end{array}$

$\begin{array}{lll}6 & 5 & 7 \\ 3 & 2 & 2 \\ 9 & 7 & 9\end{array}$

6
2
8

3
6
9

$\begin{array}{rrrrrrrrr}6 & 8 & 2 & 3 & 1 & 5 & 9 & 7 & 101 \\ 8 & 6 & 4 & 2 & 4 & 3 & 4 & 1 & 58\end{array}$

$\begin{array}{llllllllllllllll}3 & 6 & 3 & 0 & 0 & 3 & 3 & 2 & 2 & 7 & 8 & 7 & 9 & 6 & 8 & 85\end{array}$

$\begin{array}{rrrrrrrrrrrrrrrr}6 & 3 & 2 & 1 & 1 & 3 & 5 & 8 & 4 & 5 & 1 & 3 & 5 & 4 & 1 & 63 \\ 9 & 9 & 5 & 1 & 1 & 6 & 8 & 10 & 6 & 12 & 9 & 10 & 14 & 10 & 9 & 148\end{array}$

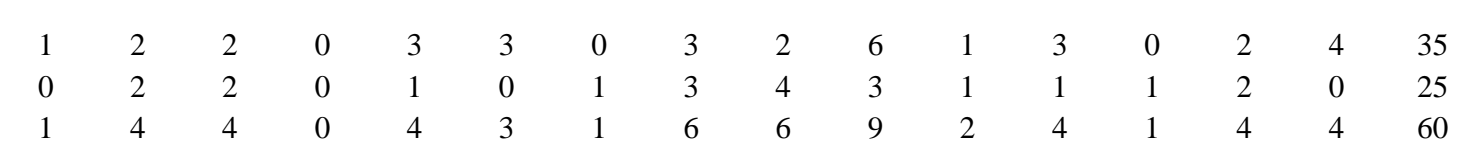

$\begin{array}{lllllll}6 & 8 & 11 & 8 & 17 & 22 & 27\end{array}$

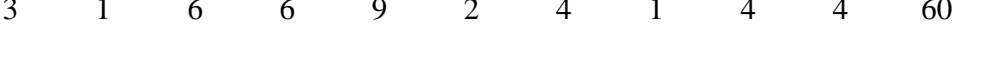

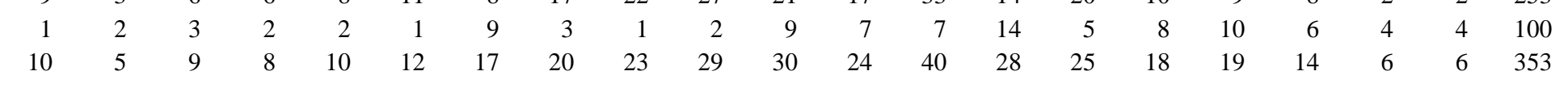

Avg No. of Topics

$\begin{array}{rrrrrrrrrrrrrrrrrrrrr}20 & 18 & 20 & 26 & 33 & 27 & 39 & 39 & 43 & 44 & 46 & 46 & 54 & 48 & 47 & 37 & 40 & 41 & 34 & 36 & 738 \\ 39 & 26 & 40 & 49 & 51 & 50 & 82 & 73 & 74 & 82 & 87 & 97 & 119 & 102 & 102 & 70 & 80 & 84 & 71 & 59 & 1437\end{array}$

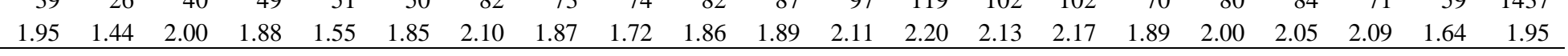


Table 5. Category pairs with significant positive correlations

\begin{tabular}{lr}
\hline Category pairs & Correlation(r) \\
\hline Access vs. ownership, resource sharing & 0.334 \\
Economics of information, serials industry & 0.210 \\
Future of serials, scholarly information issues & 0.149 \\
Future of serials, technology impact & 0.123 \\
Access vs. ownership, collection development & 0.104
\end{tabular}

${ }^{*} p<0.05$ (two-tailed)

Figure 1. Presentations and categories assigned by year

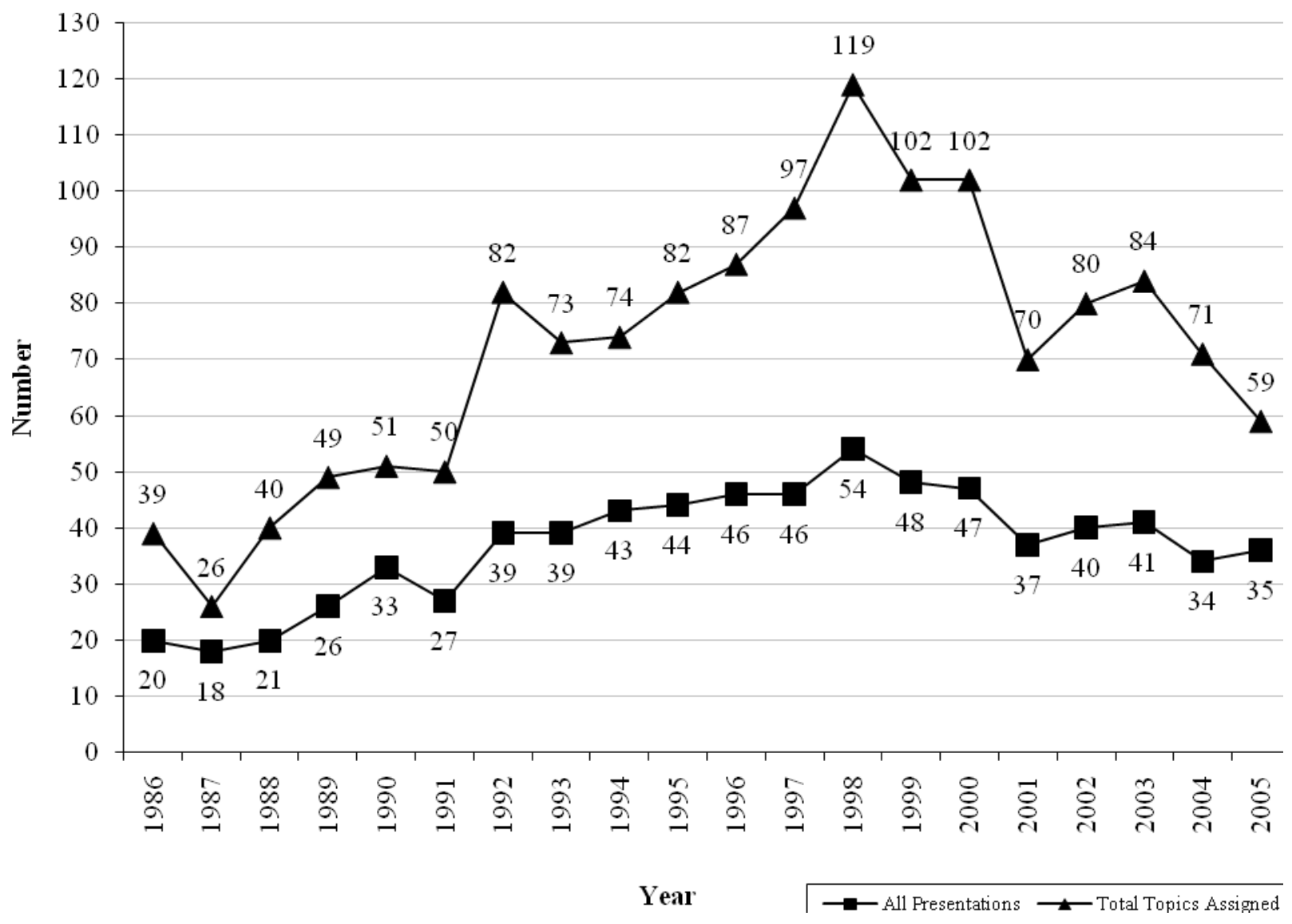


Figure 2. Technology impact presentations by year $(n=353)$

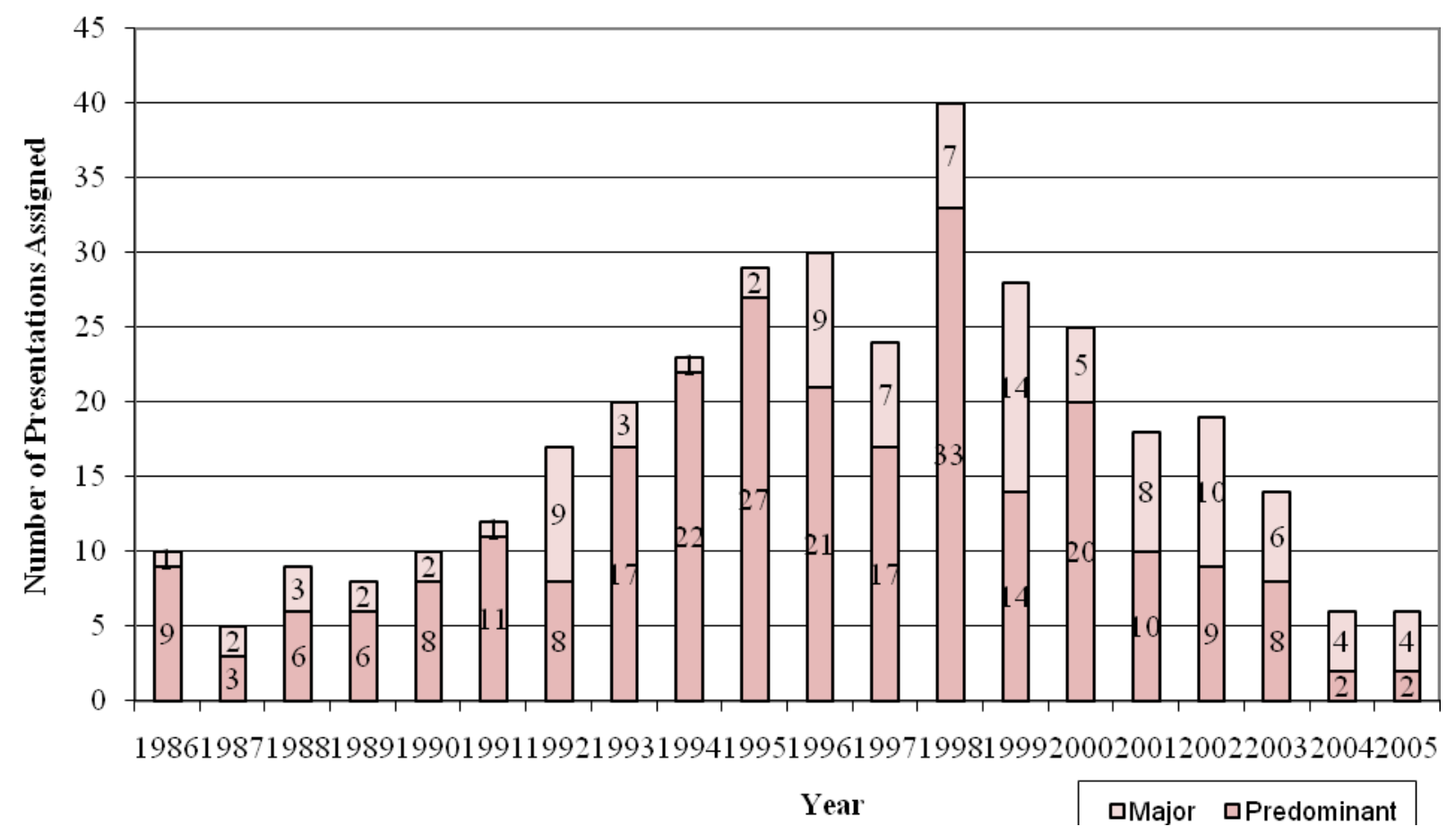

Figure 3 . Serials industry presentations by year $(n=159)$

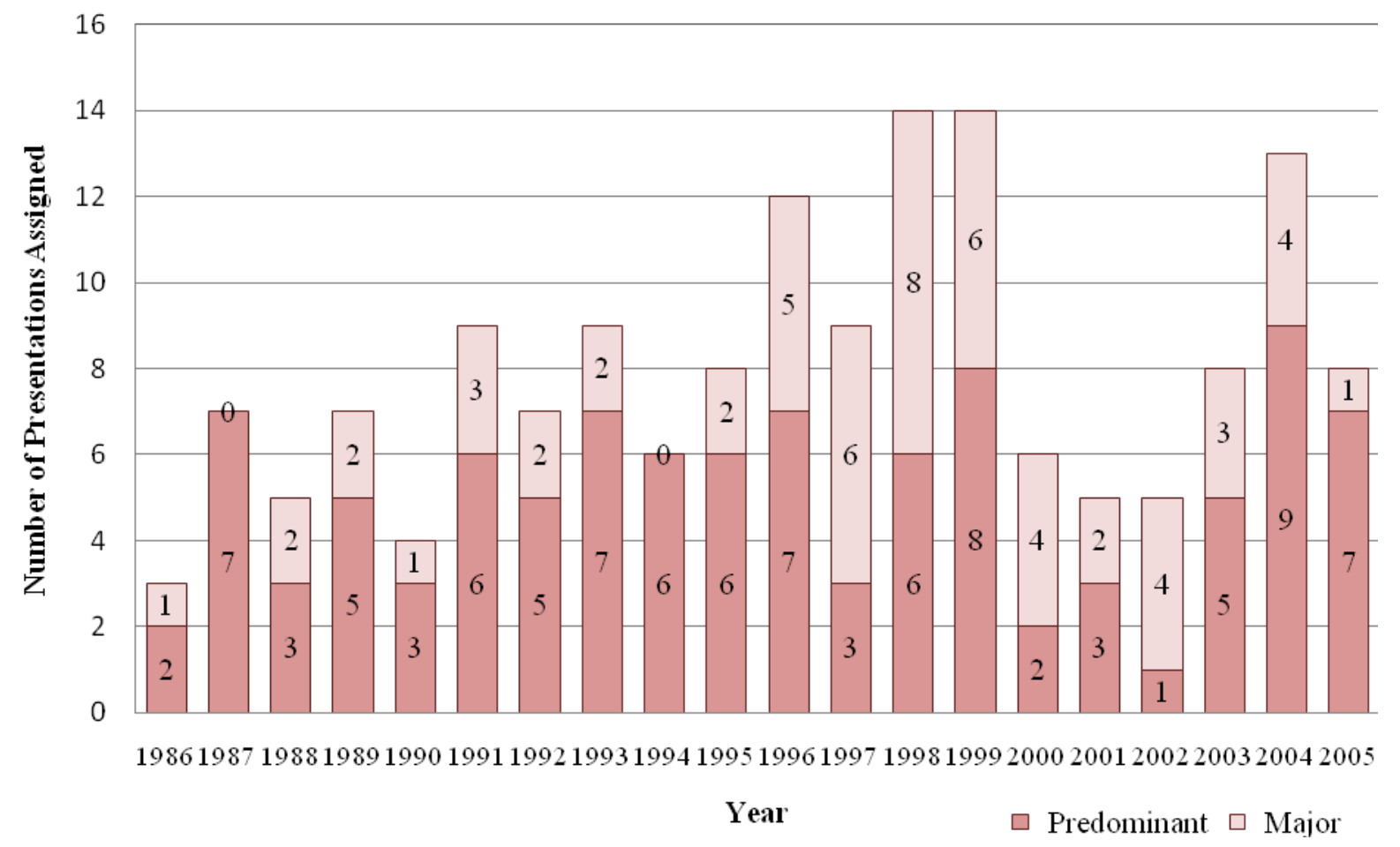


Figure 4. Serials management presentations by year $(n=148)$

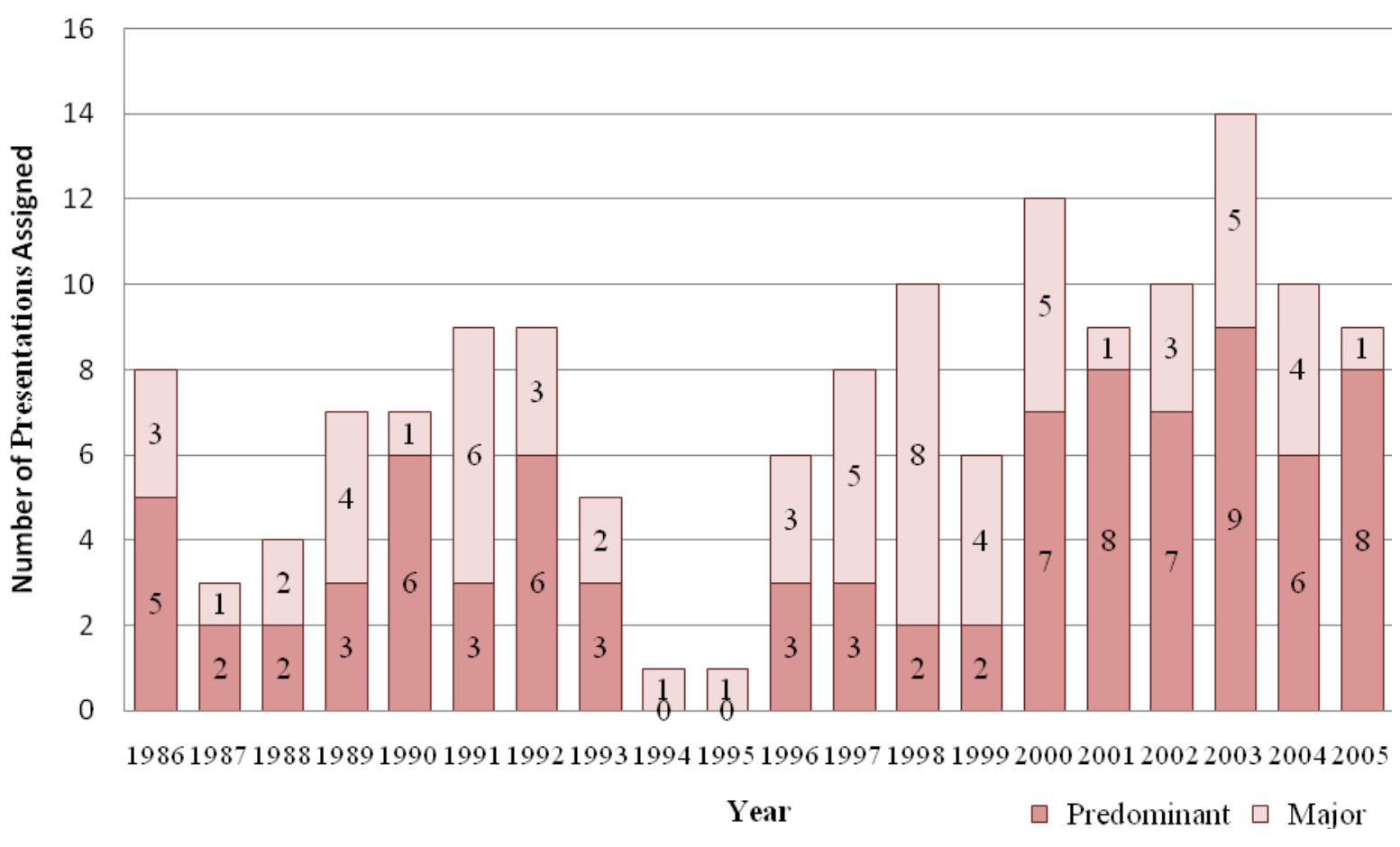

Figure 5 . Scholarly information issues presentations by year $(n=100)$

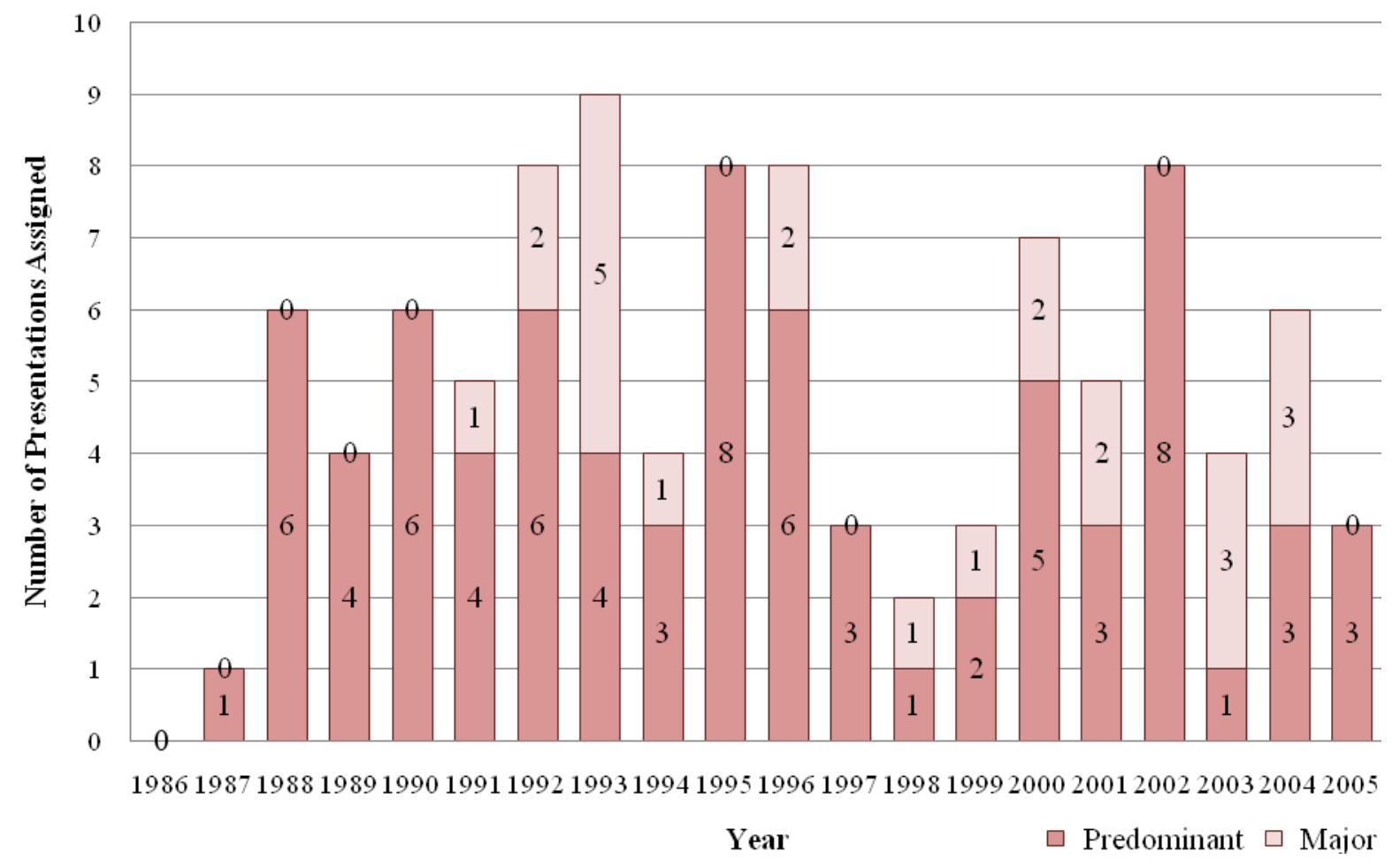

